\title{
PEMETAAN STAKEHOLDER YANG BERPERAN DALAM PENGEMBANGAN AGROWISATA MINAPADI SAMBEREMBE
}

\author{
(MAPPING OF STAKEHOLDERS THAT HAVE ROLES IN THE \\ DEVELOPMENT OF MINAPADI (MIXED FARMING) AGROTOURISM \\ OF SAMBEREMBE)
}

\author{
Yhani Chrismawati*, R Widodo Dwi Pramono*** \\ *Mahasiswa, Magister Perencanaan Wilayahdan Kota, FakultasTeknik, Universitas Gadjah Mada, Jl.Grafika \\ No.2, Sekip, Yogyakarta, 55281, Indonesia \\ Email: graceayhanich@gmail.com \\ **Dosen, Magister Perencanaan Wilayah dan Kota, Fakultas Teknik, Universitas Gadjah Mada, Jl.Grafika No.2, \\ Sekip, Yogyakarta, 55281, Indonesia
}

Diterima: 16 Juni 2021; Direvisi: 23 Desember 2021; Disetujui: 24 Desember 2021

\begin{abstract}
ABSTRAK
Alih fungsi lahan pertanian perlu dikendalikan agar lahan pertanian terutama LP2B tetap terjaga kelestariannya sehingga ketahanan pangan tetap terjaga. Di kabupaten Sleman alih fungsi lahan paling tinggi diantara kabupaten atau kota lain di D.I. Yogyakarta. Salah satu upaya konservasi LP2B ini dengan mengembangakan system pengelolaan lahan pertanian menjadi pertanian yang terintegrasi dengan kegiatan lain. Salah satunya adalah pertanian minapadi yang kemudian diberi sentuhan pariwisata "agrowisata" Agrowisata minapadi yang dikembangkan di Samberembe sebagai salah satu upaya mengendalikan alih fungsi lahan. Dalam mengembangan agrowisata ini membutuhkan peran sberbagai stakeholder. Penelitian ini dilakukan di lokasi tersebut untuk mengetahui stakeholder yang paling berpengaruh terhadap pengembangan agrowisata minapadi Samberembe dengan metode survey, Indepth interview dan study literature. Tenik analisis yang digunakan adalah stakeholder mamping. Hasil penelitian menunjukkan 4 kategori stakeholder dan yang paling berpengaruh adalah key player yang berasal dari Pemerintah daerah Kabupaten Sleman maupun masyarakat. Selain itu peran local champion dan keberhasilan kolaborasi antar stakeholder juga berpengaruh terhadap pengembangan agroowisata minapadi samberembe. Diperlukan upaya membangkitkan local champion maupun meningkatkan kolaborasi stakeholder dalam mengembangkan kegiatan ekonomi berbasis potensi lokal.
\end{abstract}

Kata kunci: alih fungsi lahan, agrowisata, minapadi, stakeholder, local champion

\begin{abstract}
The conversion of agricultural land needs to be controlled so that agricultural land, especially $L P 2 B$, is maintained so that food security is maintained. In Sleman district, land conversion is the highest among other districts or cities in D.I. Yogyakarta. One of the conservation efforts of LP2B is by developing a system of agricultural land management into agriculture that is integrated with other activities. One of them is Minapadi agriculture which is then given a touch of "Agrotourism" tourism. Minapadi agro-tourism was developed in Samberembe as an effort to control land conversion. In developing this agro-tourism requires the role of various stakeholders. This research was conducted at that location to find out the stakeholders who have the most influence on the development of agro-tourism in Minapadi Samberembe using survey methods, in-depth interviews and literature studies. The analysis technique used is the supporting stakeholder. The results showed that there were 4 categories of stakeholders and the most influential were the key players from the local government of Sleman Regency and the community. In addition, the role of local champions and the success of collaboration between stakeholders also affect the development of Minapadi Samberembe agro-tourism. Efforts are needed to generate local champions and increase stakeholder collaboration in developing economic activities based on local potential.
\end{abstract}


Keywords: land conversion, agro-tourism, mining, stakeholders, local champion localKetik abstrak bahasa inggris di sini, dengan font Times New Roman 10 (1 spasi) italic. Isi abstrak mencakup tujuan, metode, hasil kajian/penelitian beserta rekomendasi. Abstrak ditulis satu paragraf, tanpa kutipan, sumber referensi, dan footnote. Jumlah karakter kata dalam abstrak tidak lebih dari 300 kata. Untuk naskah yang ditulis dengan bahasa Indonesia, abstrak bahasa indonesia diletakkan di atas abstrak bahasa Inggris dan sebaliknya. Berisi 200 sampai 300 kata.

Keywords: land conversion, agro-tourism, mining, stakeholders, local champion local

\section{PENDAHULUAN}

Alih fungsi lahan pertanian ke non pertanian yang terus meningkat mengakibatkan lahan pertanian semakin berkurang. Hal ini jika dibiarkan terjadi lambat laun akan berdampak pada menurunnya produksi dan produktivitas padi, padahal jumlah penduduk Indonesia semakin hari semakin bertambah. Jika alih fungsi ini terus berlanjut maka akan berpengaruh kepada ketahanan pangan di Indonesia, terlebih lagi Jawa termasuk daerah lumbung beras di Indonesia. Di tahun 2015 total produksi padi di Indonesia 75.397.841 ton dan di tahun 2018 produksi padi 56.537.774 ton (BPS-Statistik Indonesia, 2017 dan 2019). Daerah Istimewa Yogyakarta termasuk salah satu provinsi yang mengalami alih fungsi lahan yang cukup besar. Terbukti dengan menjamurnya perumahan yang ada di DIY. Lahan pertanian di DIY terutama yang terletak di Kabupaten Sleman, Bantul dan Kota Yogyakarta menjadi sasaran alih fungsi lahan. Hal ini dibuktikan dengan data yang bersumber dari BPS tahun 2013 dan 2017. Dari data tersebut terlihat penurunan luas lahan pertanian di tiga bagian wilayah administrasi DIY.

Tabel 1 Penurunan Luas Lahan Sawah di DIY Tahun 2012-2016

\begin{tabular}{|c|c|c|}
\hline \multirow[t]{2}{*}{ Kabupaten/Kota } & \multicolumn{2}{|c|}{$\begin{array}{c}\text { Luas Lahan Pertanian (Sawah) } \\
\text { dalam Ha }\end{array}$} \\
\hline & 2012 & 2016 \\
\hline Kulonprogo & 10299 & 10366 \\
\hline Bantul & 15482 & 15150 \\
\hline Gunungkidul & 7865 & 7875 \\
\hline Sleman & 22642 & 21841 \\
\hline Yogyakarta & 76 & 60 \\
\hline D.I. Yogyakarta & 56364 & 55292 \\
\hline
\end{tabular}

Sumber : BPS DIY 2013 dan BPS DIY 2017

Fenomena alih fungsi lahan juga dimuat dalam Harian Tribun Jogja tanggal 29 Maret 2019 yang menyebutkan bahwa penyusutan lahan pertanian di Sleman mencapai 100 hektar pertahun karena banyak dijadikan pemukiman. Untuk itu diperlukan upaya untuk menganggulani masalah alih fungsi lahan yang terus merebak agar dampaknya tidak semakin mengancam ketahanan pangan di Indonesia. Fenomena konversi (alih fungsi) lahan pertanian ke non pertanian dipengaruhi oleh land use decision jika dilihat dari perpektif ekonomi. Menurut Sitorus dalam (Nuraeni, 2017), keputusan yang ditetapkan pemilik lahan terkait penggunaan lahan merupakan aktivitas politik yang dapat dipengaruhi oleh keadaan sosial dan ekonomi. Perilaku petani dalam pengambilan keputusan dan tindakan dipengaruhi oleh hubungan sosial diantara mereka, misalnya keputusan yang diambil oleh suatu masyarakat akan berpengaruh terhadap keputusanyang diambil oleh setiap individu. Permana, Sativa \& Nurfathiyah (2016) menyatakan bahwa terdapat ada beberapa faktor yang berpengaruh terhadap pengambilan keputusan yang dilakukan petani dalam pemanfaatan lahannya yaitu faktor motif ekonomi (faktor yang paling berpengaruh), faktor pengetahuan, faktor pengalaman, kemauan dan kebiasaan.

Upaya untuk mengendalikan konversi (alih fungsi) lahan sudah banyak dilakukan. Sudaryanto dalam Ashari (2003) menjelaskan terdapat 2 pendekatan yang digunakan dalam 
pengendalian alih fungsi lahan yaitu pendekatan ekonomi dan pendekatan kelembagaan. Pendekatan ekonomi dilakukan dengan pemberian insentif kepada petani agar tidak melakukan alih fungsi lahan maupun menjual lahannya. Dalam pendekatan ekonomi dapat ditambahkan berupa pengembangan kegiatan pertanian integratif dan memberikan sentuhan kegiatan non pertanian seperti agrowisata dalam upaya meningkatkan pendapatan petani sehingga petani tidak melakukan alih fungsi lahan pertanian.

Upaya pengembangan kegiatan pertanian integratif yang dibalut wisata "agrowisata" diharapkan akan mendatangkan keuntungan bagi masyarakat lokal. Salah satunya meningkatkan pendapatan petani sehingga petani tertarik untuk bertani maupun melestarikan lahan pertaniannya. Untuk lebih menarik minat petani dibutuhkan contoh praktek nyata pengembangan pertanian agrowisata yang mempunyai prospek menguntungkan. Salah satu praktek agrowisata yang sudah dikembangkan di Kabupaten Sleman yaitu agrowisata minapadi Samberembe.

Dalam pengembangan agrowisata tentunya melibatkan berbagai stakeholder di dalamnya. Dimana setiap stakeholder mempunyai peran masing-masing. Dan dengan adanya kolaborasi antar stakeholder di dalam suatu proyek akan berpengaruh terhadap keberhasilan proyek tersebut. Penelitian tentang stakeholder sudah banyak dilakukan, berikut ini beberpa contoh penelitian tersebut. Penelitian yang dilakukan Simanjutak \& S.Sariffuddin (2017) lebih berfokus pada peran local champion dalam pengembangan desa wisata. Penelitian Fairuza (2017) memfokuskan pada peran kolaborasi stakeholder dalam pengembangan sektor pariwisata. Penelitian Mahfud, Haryono \& Anggraeni (2015) tentang pengembangan kawasan minapolitan melalui peran dan koordinasi antar stakeholder yang terlibat.Sedangkan penelitian berfokus pada pemetaan stakeholder (local champion maupun kolaborasi stakeholder) terkait pengembangan agrowisata minapadi dalam rangka konservasi LP2B. Tujuan dari penelitian ini untuk menentukan stakeholder yang paling berpengaruh dan perannya terdahap pengembangan agrowisata minapadi Samberembe.

Iqbal dan Sumaryanto dalam (Peswita \& Harini, 2013) menyatakan bahwa alih fungsi lahan pertanian yang tidak terkendali dan tidak ditanggulangi dapat menyebabkan permasalahan yang serius yaitu mengancam kapasitas penyediaan pangan. Salah satu cara untuk mengendalikannya dengan mengembangkan usaha pertanian terpadu, misalnya pertanian minapadi. Dan akan lebih menguntungkan lagi jika dibalut dengan pariwisata, hal ini sejalan dengan Utama (2015) menyatakan bahwa :

"agrowisata merupakan bagian dari pariwisata yang memanfaatkan usaha pertanian (agro) sebagai objek wisata dengan tujuan untuk memperluas pengetahuan, pengalaman rekreasi, dan hubungan usaha dibidang pertanian. Dengan berintegrasi dengan agrowisata akan mendatangkan keuntungan dari pertanian padi dan ikan serta pendapatan dari wisatawan yang berkunjung."

Pengembangan agrowisata dipengaruhi oleh beberapa faktor. Terkait dengan agrowisata di lahan sawah, perkembangnnya belum sebanyak agrowisata di lahan pertanian hortikultura. Handayani (2016) menyimpulkan bahwa :

a. Agrowisata bisa banyak diminati generasi muda pengembangan agrowisata tersebut berbasis edukasi usaha tani padi sawah tradisional .

b. Manfaat yang didapat dari agrowisata berbasis usaha tani padi sawah tradisional antara lain meningkatkan pendapatan masyarakat yang terlibat secara langsung maupun tidak langsung dalam kegiatan agrowisata.

Pengembangan agrowisata tidak terlepas dari peran stakeholder. Hertifah dalam (Mahfud, Haryono \& Anggraeni, 2015) menyatakan bahwa stakeholder merupakan individu maupun kelompok organisasi yang memiliki kepentingan, terlibat dalaam suatu kegiatan program pembangunan yang sifatnya bisa mempengaruhi atau dipengaruhi atau bahkan keduanya baik positif atau negatif Menurut (Reed et al., 2009; Thompson, 2011; Gardner et al., 1986) dalam 
penelitian (Wakka, 2014) stakeholder diklasifikasikan menjadi 4 berdasarkan kepentingan dan pengaruhnya yaitu :

a. Subyek (Subjects) yaitu stakeholders yang memiliki tingkat kepentingan yang tinggi tetapi pengaruh yang rendah.

b. Pemain Kunci (Key Players) yaitu stakeholders yang memiliki tingkat kepentingan dan pengaruh yang tinggi.

c. Pengikut Lain (Crowd) yaitu stakeholders yang memiliki tingkat kepentingan dan pengaruh yang rendah.

d. Pendukung (Contest setters) yaitu stakeholders yang memiliki tingkat kepentingan yang rendah tetapi pengaruh yang tinggi

Dalm suatu proyek, berbagai stakeholder yang berperan di dalamnya biasanya membentuk suatu kolaborasi. Patminingtyas (2020) mengungkapkan bahwa kolaborasi stakeholder adalah suatu bentuk kerjasama dan interakasi sosial dimana para pemangku kepentingan memiliki peran dalam pengambilan kebijakan dan sebagai aktor dalam rangka mendorong masyarakat untuk melakukan perubahan untuk mencapai tujuan - tujuan yang telah ditetapkan sebelumnya. Stakeholder yang berperan dalam pengembangan potensi lokal tidak terlepas dari peran local champion. Local champion merupakan seseorang yang mempunyai inisiatif untuk melakukan proses perubahan terhadap masyarakat maupun suatu lembaga dimana ia harus mampu menjaga hubungan antara pemimpin-pengikutnya dan pada akhirnya ia mampu berperan sebagai mediator, fasilitator dan juga sebagai mobilisator menurut Ecopolan international dalam (Simanjutak \& S.Sariffuddin, 2017).

Lingkup amatan pada penelitian ini adalah kawasan agrowisata minapadi Samberembe, Candibinangun, Pakem, Sleman. Penelitian dilakukan pada bulan Februari hingga Mei 2021. Jenis data dalam penelitian ini berupa data primer dan sekunder. Data primer dikumpulkan dengan cara observasi, dokumentasi dan indepth interview dengan stakeholder yang terkait dengan pengembangan agrowisata minapadi Samberembe baik dari kalangan petani, pengelola agrowisata maupun birokrat. Pengambilan sampel menggunakan teknik purposive sampling yaitu teknik pengambilan sampel dengan pertimbangan tertentu (Sugiyono, 2017). Sedangkan data sekunder diperoleh dari berbagai dokumen, laporan, informasi, dan berbagai data literatur yang telah dipublikasikan.

Analisis data yang digunakan dalam penelitian ini adalah stakeholder mapping yang dilakukan berdasarkan hasil indepth interview dan observasi maupun studi literature. Dalam pemetaan stakeholder langkah pertama yang terlebih dahulu dilakukan adalah mengidentifikasi seluruh stakeholder yang terlibat dalam pengembangan agrowisata baik secara langsung maupun tidak langsung. Pemetaan stakeholder berdasarkan analisis kepentingan dan pengaruh dari masing-masing stakeholder. Tingkat kepentingan stakeholder diukur menggunakan 4 indikator, sedangkan tingkat pengaruh stakeholder diukur dengan menggunakan 3 indikator. Berikut matriks untuk mengukur tingkat pengaruh dan kepentingan stakeholder dalam pengembangan agrowisata minapadi Samberembe. 
Pemetaan Stakeholder Yang Berperan Dalam Pengembangan Agrowisata Minapadi Samberembe Yhani Chrismawati, R Widodo Dwi Pramono

Tabel 2 Kriteria Penilaian Tingkat Kepentingan Stakeholder dalam Pengembangan Agrowisata Minapadi Samberembe

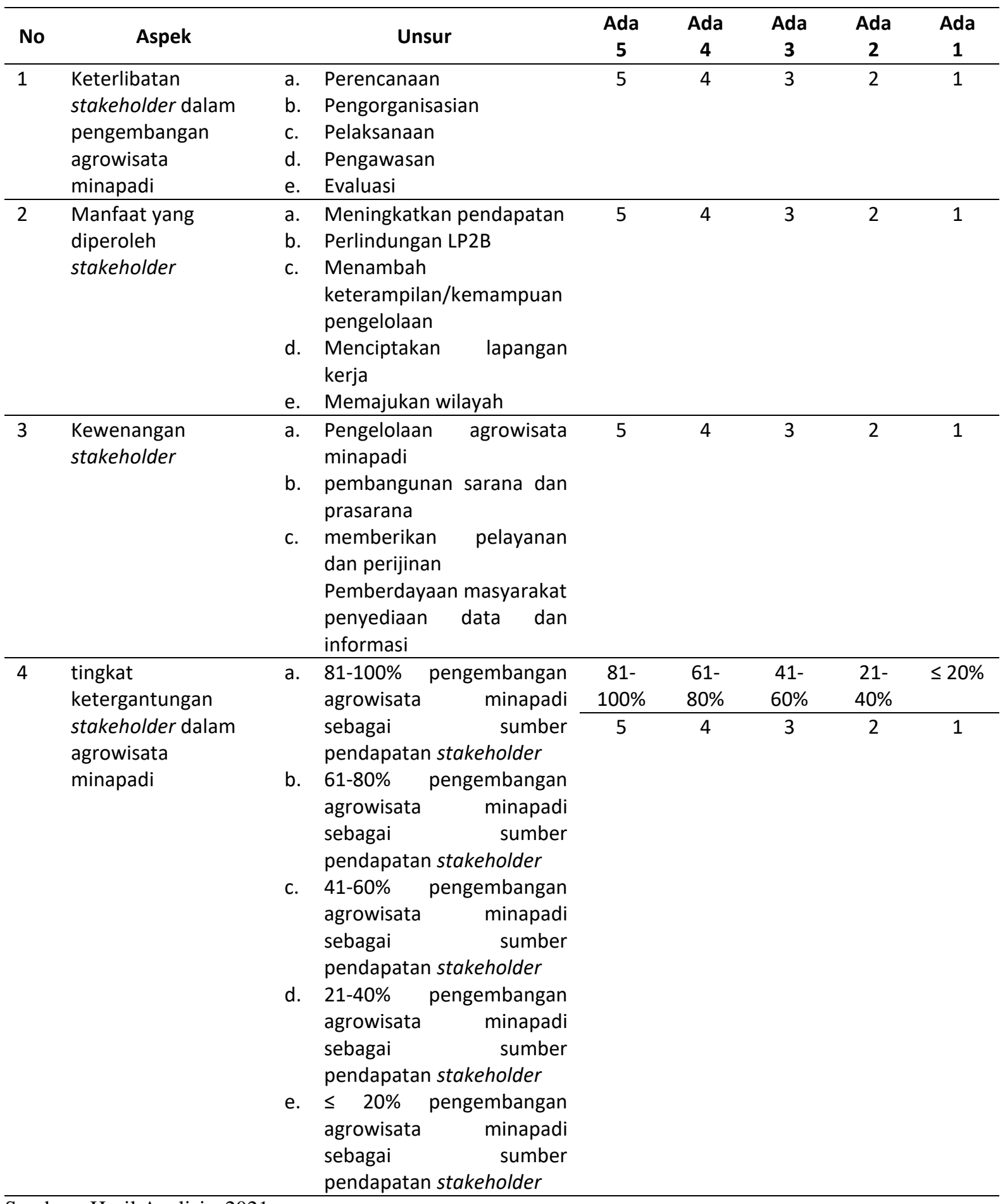

Sumber : Hasil Analisis, 2021 
Tabel 3 Kriteria Penilaian Tingkat Pengaruh Stakeholder dalam Pengembangan Agrowisata Minapadi Samberembe

\begin{tabular}{|c|c|c|c|c|c|c|c|c|}
\hline No & Aspek & & Unsur & $\begin{array}{c}\text { Ada } \\
5\end{array}$ & $\begin{array}{c}\text { Ada } \\
4\end{array}$ & $\begin{array}{c}\text { Ada } \\
3\end{array}$ & $\begin{array}{c}\text { Ada } \\
2\end{array}$ & $\begin{array}{c}\text { Ada } \\
1\end{array}$ \\
\hline 1 & $\begin{array}{l}\text { Kontribusi } \\
\text { stakeholder } \\
\text { dalam } \\
\text { pengembangan } \\
\text { agrowiata } \\
\text { minapadi }\end{array}$ & $\begin{array}{l}\text { a. } \\
\text { b. } \\
\text { c. } \\
\text { d. } \\
\text { e. }\end{array}$ & $\begin{array}{l}\text { Penyedia sarana dan } \\
\text { prasarana } \\
\text { Penyedia peralatan } \\
\text { pendukung } \\
\text { Penyedia fasilitas pelatihan } \\
\text { dan pendampingan } \\
\text { Penyedia dana } \\
\text { Penyedia tenaga } \\
\text { pengelolaan }\end{array}$ & 5 & 4 & 3 & 2 & 1 \\
\hline 2 & $\begin{array}{l}\text { Kemampuan } \\
\text { stakeholder } \\
\text { dalam } \\
\text { pengembangan } \\
\text { agrowiata } \\
\text { minapadi }\end{array}$ & $\begin{array}{l}\text { a. } \\
\text { b. } \\
\text { c. } \\
\text { d. } \\
\text { e. }\end{array}$ & $\begin{array}{l}\text { Pengelolaan agrowisata } \\
\text { minapadi } \\
\text { Kemampuan pelayanan dan } \\
\text { perijinan } \\
\text { kemampuan promosi } \\
\text { Kemampuan pelatihan dan } \\
\text { pendampingan SDM } \\
\text { Kemampuan menjalin } \\
\text { hubungan dengan } \\
\text { stakeholder }\end{array}$ & 5 & 4 & 3 & 2 & 1 \\
\hline 3 & $\begin{array}{l}\text { Dukungan } \\
\text { anggaran } \\
\text { stakeholder } \\
\text { dalam }\end{array}$ & a. & $\begin{array}{l}81-100 \% \text { untuk } \\
\text { pengembangan agrowisata } \\
\text { minapadi }\end{array}$ & $\begin{array}{c}81- \\
100 \%\end{array}$ & $\begin{array}{l}61- \\
80 \%\end{array}$ & $\begin{array}{l}41- \\
60 \%\end{array}$ & $\begin{array}{l}21- \\
40 \%\end{array}$ & $\begin{array}{c}\leq \\
20 \%\end{array}$ \\
\hline & $\begin{array}{l}\text { pengembangan } \\
\text { agrowisata }\end{array}$ & b. & $\begin{array}{l}\text { pengembangan agrowisata } \\
\text { minapadi }\end{array}$ & 5 & 4 & 3 & 2 & 1 \\
\hline & minapadi & c. & $\begin{array}{l}41-60 \% \text { untuk } \\
\text { pengembangan agrowisata } \\
\text { minapadi }\end{array}$ & & & & & \\
\hline & & d. & $\begin{array}{l}21-40 \% \text { untuk } \\
\text { pengembangan agrowisata } \\
\text { minapadi }\end{array}$ & & & & & \\
\hline & & e. & $\begin{array}{l}\leq 20 \% \text { untuk } \\
\text { pengembangan agrowisata } \\
\text { minapadi }\end{array}$ & & & & & \\
\hline
\end{tabular}

Sumber : Hasil Analisis, 2021

\section{HASIL DAN PEMBAHASAN}

Agrowisata Minapadi Samberembe

Tahun pertengahan 2019 Dusun Samberembe ditunjuk sebagai tuan rumah atau penyelenggara Pekan Daerah Petani Nelayan - Kontak Tani Nelayan Andalan (Peda-KTNA) DIY. Agar masyarakat tidak hanya menjadi penonton maka timbulah inisiatif karang taruna untuk membentuk pokdarwis. Hal ini dilakukan untuk mendukung kegiatan Peda-KTNA dengan fokus pada wisata teknologi perikanan dan pertanian. Untuk mendukung adanya wisata tentunya membutuhkan infrastruktur pendukung, seperti tempat transit maupun toilet. Kelompok mengajukan pinjaman Kredi Usaha Rakyat (KUR) untuk membangun fasilitas tersebut. Dengan basic pertanian perikanan dan konsep wisata juga dimasukkan, akhirnya ada respon baik dari pemerintah bahkan dibuat masterplannya berupa gambaran agrowisata oleh pihak ketiga sehingga ada gambaran rencana pengembangaan kawasan kedepannya.

Untuk rencana kedepannya tidak akan melibatkan investor swasta. Jadi tidak akan menerima investor masuk karena mereka hanya berorintasi pada bisnis dan masyarakat hanya 
sebagai penonton dan paling bagus jadi pekerrja. Untuk agrowisata minapadi ini milik kelompok yang dikelola secara kelompok dan jika ada keuntungan dibagi untuk kelompok. Kawasan agrowisata ini termasuk kolam dan pertanian mencapai 3 hektar. Dalam persiapan awalnya adalah penyiapan lahan. Dan lahan yang digunakan ini adalah lahan yang dikelola berkelompok. Agrowisata yang dikembangkan berfokus pada wisata edukasi. Bahkan pernah mendapat kunjungan dalam rangka studi banding oleh 15 negara Asia Pasifik.

Agrowisata ini bermula dari maraknya kaum muda yang sudah meninggalkan pertanian dan tinggal petani yang tua yang mengerjakan sawah. Kondisi yang memprihatinkan ini lamakelamaan akan berimbas pada lahan sawah akan habis dijual. Maka timbul inisiatif dari salah satu pemuda untuk mencoba mengembangkan pertanian yang inovatif yaitu dengan pertanian minapadi yang sudah mulai berkembang duluan dan diberi sentuhan estetik dan teknologi menjadi agrowisata. Dengan harapan banayak pemuda yang menjadi tertarik dengan pertanian yang dibalut dengan wisata sehingga lahan pertanian tetap dilestarikan sekaligus mengurangi angka pengangguran.

Agrowisata yang ingin dikembangkan di Samberembe ini adalah agrowisata edukasi berbeda dengan tempat yang lain maupun yang berkembang saat ini. Hal ini dianggap akan lebih survival dan eksis karena kalau hanya sekedar wisata swafoto yang menawarkan berbagai spot keindahan alam sudah banyak dibuka dan biasanya pengunjung hanya sekali datang (pengunjung foto di spot yang viral kemudian diunggah di media sosial, setelah itu pengunjung tidak akan datang lagi jika tidak ada inovasi baru lagi). Sehingga untuk wisata fokus spot swafoto, pengelola harus kreatif menemukan spot-spot swafoto baru.

\section{Identifikasi Stakeholder}

Dalam pengembangan agrowisata minapadi Samberembe selama ini telah melibatkan berbagai stakeholder. Untuk lebih memahami, mendukung dan membuktikan faktor keempat yang berpengaruh terhadap pengembangan agrowisata minapadi Samberembe maka akan dilakukan stakeholder mapping. Langkah pertama yang dilakukan dalam analisis ini adalah identifikasi stakeholder. Setiap stakeholder mempunyai peran masing-masing sesuai fungsinya dalam pengembangan argowisata minapadi Samberembe. Stakeholder tersebut dapat diklasifikasikan ke dalam empat kategori yaitu pemerintah pusat, pemerintah daerah, swasta dan masysrakat. Klasifikasi stakeholder tersebut dapat dilihat dalam Tabel 4.

Berdasarkan identifikasi stakeholder di atas terdapat 4 kategori stakeholder dengan 19 stakeholder yang berpengaruh dalam pengembangan agrowisata minapadi Samberembe. Penjabaran keempat stakeholder tersebut yaitu:

\section{Pemerintah Pusat}

Stakeholder dari pemerintah pusat yang ikut berperan dalam pengembangan agrowisata minapadi Samberembe adalah Kementerian Kelautan dan Perikanan Republik Indonesia. Direktorat Jenderal Perikanan Budidaya Kementerian Kelautan dan Perikanan (DJPBKKP) sangat mendukung prospek minawisata pada lahan budidaya ikan sistem minapadi di Samberembe ini. Selain itu KKP juga memberikan apresiasi kepada masyarakat Desa Samberembe yang berhasil mengembangkan potensi lahan melalaui pertanian minapadi sekaligus agrowisata edukasi.

2. Pemerintah Daerah

Stakeholder dari pemerintah daerah yang ikut berperan dalam pengembangan agrowisata minapadi Samberembe meliputi pemerintah daerah yang berkedudukan di tingkat provinsi hingga tingkat desa.

3. Swasta

Swasta merupakan stakeholder yang terlibat dalam penyediaan dana maupun pelatihan SDM untuk pengembangan agrowisata minapadi Samberembe. Penyediaan dana berkaitan dengan pengadaan sarana dan prasarana pertanian minapadi dan agrowisata minapadi. 
Sarana dan prasarana ini harus sebagai syarat kelengkapan suatu obyek wisata maupun sebagai wahana dan daya tarik yang disediakan oleh agrowisata minapadi Samberembe

4. Masyarakat

Masyarakat merupakan stakeholder penting dalam pengembangan agrowisata minapadi Samberembe. Hal ini dikarenakan masyarakat merupakan inti dari pengembangan agrowisata ini. Kemajuan, tetap beroperasinya agrowisata maupun pertanian minapadi sangat tergantung SDM yang merupakan anggota masyarakat.

Tabel 4 Stakelholder yang Berperan dalam Pengembangan Agrowisata Minapadi Samberembe

\begin{tabular}{|c|c|c|}
\hline No & Kategori Stakeholder & Stakeholder \\
\hline 1 & Pemerintah Pusat & $\begin{array}{l}\text { Kementerian Kelautan dan Perikanan Republik } \\
\text { Indonesia }\end{array}$ \\
\hline \multirow[t]{9}{*}{2} & Pemerintah Daerah & a. Dinas Pariwisata DIY \\
\hline & & b. Dinas Pariwisata Kabupaten Sleman \\
\hline & & Dinas Pertanian dan Ketahanan Pangan DIY \\
\hline & & $\begin{array}{l}\text { d. Dinas Pertanian Pangan dan Perikanan } \\
\text { Kabupaten Sleman }\end{array}$ \\
\hline & & e. Dinas Kelautan dan Perikanan DIY \\
\hline & & Bappeda Kabupaten Sleman \\
\hline & & $\begin{array}{l}\text { g. Dinas Pertanahan dan Tata Ruang } \\
\text { Kabupaten Sleman }\end{array}$ \\
\hline & & Pemerintah Kapanewon Pakem \\
\hline & & i. Pemerintah Desa Candibinangun \\
\hline \multirow[t]{3}{*}{3} & Swasta & a. Bank Rakyat Indonesia (BRI) \\
\hline & & b. Bank Pembangunan Daerah (BPD DIY) \\
\hline & & $\begin{array}{l}\text { c. Rumah Zakat, Laznas BSM, dan Bank Mandiri } \\
\text { Syariah }\end{array}$ \\
\hline \multirow[t]{6}{*}{4} & Masyarakat & $\begin{array}{l}\text { a. Kelompok Sadar Wisata Kampung Minapadi } \\
\text { Samberembe }\end{array}$ \\
\hline & & b. Kelompok Tani “Ngudi Lestari” \\
\hline & & c. Kelompok Wanita Tani Samberembe \\
\hline & & d. Kelompok Perikanan “Mina Muda” \\
\hline & & e. Karang Taruna Dusun Samberembe \\
\hline & & f. Poklahsar Mina Laras Mandiri Pakem \\
\hline
\end{tabular}

Sumber : Hasil Analisis, 2021

\section{Identifikasi Peran Stakeholder}

Setiap stakeholder yang terlibat dalam pengembangan agrowisata minapadi Samberembe memiliki peran masing-masing. Berdasarkan hasil identifikasi dapat diketahui peran masingmasing stakeholder dalam pengembangan agrowisata minapadi Samberembe, yaitu :

1. Kementerian Kelautan dan Perikanan Republik Indonesia

Direktorat Jenderal Perikanan Budidaya Kementerian Kelautan dan Perikanan (DJPBKKP) sangat mendukung dan memberikan apresiasi positif dalam pengembangan potensi budidaya lahan pertanian dengan menggabungkan sektor pertanian, perikanan bahkan hingga agrowisata edukasi di Samberembe ini. Dalam pengembangan agrowisata minapadi Samberembe ini KKP berperan sebagai instansi nyang memberikan bantuan dalam proses pengembangannya. Bantuan tersebut berupa benih, pakan, penyediaan lahan untuk pengembangan minapadi. Selain itu KKP juga memberikan bantuan berupa mesin pakan 
untuk program pakan mandiri dan paket budidaya ikan sistem bioflok, kulkas frozen dan mesin kincir air serta memberikan pendampingan dan pelatihan teknis.

2. Dinas Pariwisata DIY

Dinas Pariwisata DIY memiliki fungsi antara lain memfasilitasi pengelolaan daya tarik wisata, kawasan strategis, industri dan pemasaran pariwisata serta pelaksanaan kerjasama lintas sektor dalam pengelolaan daya tarik wisata, kawasan strategis, industri dan pemasaran pariwisata. Berakaitan dengan fungsi tersebut, peran Dinas Pariwisata DIY dalam pengembangan agrowisata minapadi Samberembe antara lain memfasilitasi pengelolaan agrowisata minapadi Samberembe ini dengan memberikan bantuan berupa pembangunan sarana dan prasarana berupa alat-alat kesehatan (untuk pencegahan covid 19) yaitu handanitizer 1 dus, masker 200 kotak @ 50 lembar masker, vitamin dan wastafel untuk cuci tangan 3 buah. Sarana prasarana ini semakin membuat agrowisata minapadi Samberembe taat protocol kesehatan. Jadi selama pandemi ini para pengunjung wajib mentaati protokol kesehatan. Pembangunan toilet difabel, toilet VIP, lampu hias, jalur taman dan permainan. Dengan adanya sarana prasarana ini agrowisata minapadi Samberembe semakin lengkap fasilitas pendukung pariwisata yang dimilikinya.

3. Dinas Pariwisata Kabupaten Sleman

Salah satu fungsi Dinas Pariwisata Kabupaten Sleman dalam rangka melaksanakan tugasnya yaitu pelaksanaan, pelayanan, pembinaan, dan pengendalian urusan pemerintahan bidang pariwisata. Berdasarkan fungsi tersebut Dinas Pariwisata Kabupaten Sleman mempunyai peran yang penting dalam pengembangan agrowisata minapadi Samberembe. Dinas ini mengukuhkan terbentuknya pokdarwis Samberembe dan memberikan pelatihan, pendampingan dalam pengembangan agrowisata minapadi Samberembe ini. selain itu juga memberikan bantuan berupa pembangunan toilet difabel, toilet VIP, lampu hias, jalur taman dan permainan. Dengan adanya sarana prasarana ini agrowisata minapadi Samberembe semakin lengkap fasilitas pendukung pariwisata yang dimilikinya.

4. Dinas Pertanian dan Ketahanan Pangan DIY

Dinas Pertanian dan ketahanan Pangan DIY sebagai dinas yang bertanggung jawab mengamankan Lahan Pertanian Pangan Berkelanjutan (LP2B) di DIY sesuai amanat UU No. 41 Tahun 2009 tentang perlindungan LP2B dengan luasan berdasarkan Perda DIY No.5 tahun 2019 tentang RTRW DIY. Luasan LP2B ini tidak boleh berkurang sehingga perlu tindakan yang dapat mencegah terjadinya alih fungsi lahan pertanian ke lahan non pertanian. Salah satunya dengan pengembangan agrowisata di LP2B. Pengembangan agrowisata ini dapat meningkatkan pendapatan petani. Sebagai contohnya adalah agrowisata minapadi Samberembe, yang mengembangkan pertanian padi yang dikolaborasikan dengan perikanan nila dalam 1 lahan sehingga petani dapat memanen 2 komoditas secara langsung. Selain itu juga mengembangkannya menjadi agrowisata edukasi yang dilengkapi dengan spot selfi dan area bermain anak. Dari 1 lahan pertanian dapat mengahasilkan pendapatan dari 3 sumber yang berbeda. Dinas ini sangat mendukung pengembangkan agrowisata minapadi di Samberembe ini, sebagai percontohan agrowisata minapadi.

5. Dinas Pertanian Pangan dan Perikanan Kabupaten Sleman

Dinas Pertanian Pangan dan Perikanan Kabupaten Sleman merupakan dinas yang secara langsung melakukan pendampingan pada pelaksanaan pertanian minapadi. Pendampingan dilakukan baik dari pertanian maupun perikanannya. Pertanian minapadi Samberembe ini dijadikan sebagai percontohan oleh Dinas Pertanian Pangan dan Perikanan Kabupaten Sleman bagi kelompok tani dari wilayah lain yang mau mengembangkan minapadi.

Dinas ini juga bertugas mengamankan luasan LP2B dan sangat mendukung dengan adanya agrowisata minapadi ini. Dengan adanya pertanian minapadi ini mencegah terjadinya konversi lahan. Selain itu juga dengan adanya pengembangan komoditas 
pertanian yang tidak hanya mina padi, tapi juga mina cabai, mina mentimun, mina bawang merah dan lain-lain.

6. Dinas Kelautan dan Perikanan DIY

Dinas kelautan dan Perikanan DIY sudah mulai berperan dalam agrowisata minapadi ini sejak tahun 2019 yaitu sejak diadakannya Peda-KTNA di Samberembe. Dengan minapadi ini harapannya kebutuhan protein masyarakat terpenuhi. Dalam setiap masa panen tidak hanya kebutuhan akan bahan pokok (karbohidrat) saja yang tersedia namun sumber protein juga tersedia. Budidaya makan ikan setiap hari dapat terwujud.

7. Bappeda Kabupaten Sleman

Bappeda Kabupaten Sleman berperan perencanaan pembangunan daerah, salah satunya dalam pembangunan wilayah dalam rangka mempertahankan lahan pertanian sekaligus meningkatkan pendapatan masyarakat. Bappeda berperan mendorong agar program agrowisata minapadi dapat terlaksana dengan lancar. Dengan mendukung program ini tidak hanya melestarikan lahan pertanian tapi juga meningkatkan pendapatan masysrakat sekaligus meningkatan memperdayakan masysrakat serta menambah destinasi wisata di Sleman.hal ini dapat meningkatkan pendapatan daerah.

8. Pertanahan dan Tata Ruang Kabupaten Sleman

Dinas Pertanahan dan Tata Ruang Kabupaten Sleman sebagai dinas yang tetap harus ikut mengamankan lahan pertanian di Kabupaten Sleman sesuai amanat Perda DIY No.5 tahun 2019 tentang RTRW DIY tentu saja mempunyai peran juga dalam pengembangan agrowisata minapadi Samberembe. Dengan pengembangan agrowisata ini berarti lahan pertanian di Kabupaten Sleman khususnya di Samberembe ini tidak berkurang karena alih fungsi lahan.

Dinas Pertanahan Tata Ruang Kabupaten Sleman merupakan dinas yang memberikan ijin pengembangan agrowisata berdasarkan rencana tata ruang (pola ruang dan struktur ruangnya) yang ditetapkan di Kabupaten Sleman. Dinas ini mendukung usaha pengembangan agrowisata ini karena agrowisata minapadi ini justru mempertahankan lahan pertanian dan mengembangkannya menjadi pertanian minapadi dengan pengelolaan bersama (cooperative farming).

9. Pemerintah Kapanewon Pakem

Pemerintah Kapanewon Pakem secara tidak langsung juga ikut bereperan dalam pengembangan agrowisata minapadi Samberembe. Pemerintah Kapanewon Pakem sebagai instansi yang turut memperlancar usaha pengembangan agrowisata ini terkait dengan pemberian ijin, pengajuan proposal pengembangan baik ke pemerintah daerah maupun ke pihak swasta.

Pemerintah Kapanewon Pakem tentunya juga ikut dalam upaya mendukung usaha pengambangan agrowisata ini. Harapannya dengan keberadaan agrowisata ini akan berdampak positif bagi pemerintah Kapanewon Pakem maupun masyarakat.

10. Pemerintah Desa Candibinangun

Dusun Samberembe adalah dusun yang terletak di wilayah administrasi Desa Candibinangun. Desa Candibinangun mendapat kesempatan menjadi desa yang dikembangkan berdasarkan program Desa BSM (Desa Bina Sejahtera Mandiri). Dengan mendapat program ini maka Desa Candibinangun ini memperoleh bantuan dana pengembangan desa. Salah satunya untuk pengembangan mina wisata techno park minapadi.

Peran Desa Candibinangun dalam pengembangan agrowisata minapadi ini adalah sebagai pemberi ijin untuk pengembangan agrowisata minapadi sekaligus sebagai instansi pemerintah yang ikut mendukung pengembangan agrowisata minapadi ini.

11. Bank Rakyat Indonesia (BRI)

Bank Rakyat Indonesia merupakan salah satu bank milik pemerintah yang menjangkau hingga wilayah perdesaan di seluruh Indonesia. Bank ini menawarkan layanan 
yang mudah dan cepat untuk berbagai kebutuhan masyarakat. Salah satunya untuk pengembangan usaha keci/UMKM. Bank BRI menawarkan Kredit Usaha kecil (KUR).

Dalam pengembangan agrowisata minapadi Samberembe, BRI berperan sebagai bank yang memberi pinjaman bersama melalui KUR. Pinjaman yang diberikan berjangka waktu 2 tahun.

12. Bank Pembangunan Daerah Istimewa Yogyakarta (BPD DIY)

Bank Pembangunan Daerah Istimewa Yogyakarta (BPD DIY) termasuk Badan Usaha Milik daerah (BUMD) di DIY. BPD DIY mempunyai tujuan untuk membantu mendorong pertumbuhan perekonomian sekaligus pembangunan daerah di segala bidang serta menjadi salah satu salah satu sumber pendapatan daerah dalam rangka meningkatkan taraf hidup rakyat.

Berkaitan dengan tujuan tersebut BPD DIY juga ikut berperan dalam poengembangan agrowisata minapadi Samberembe. Peran BPD DIY yaitu memberikan dana hibah untuk pembangunan ifrastruktur/sarana dan prasarana penunjang obyek wisata yaitu pembangunan tempat parkir, mushola dan toilet.

13. Bank Mandiri Syariah dan Rumah Zakat, Laznas BSM

Pemerintah Kabupaten Sleman, Bank Mandiri Syariah, Rumah Zakat, dan Laznas BSM bekerjasama melalui Program Desa Berdaya Sejahtera Mandiri (BSM) Mina Wisata Techno Park Mina Padi. Desa Candi Binangun merupakan salah satu desa yang dipilih untuk dikembangkan melalui program BSM karena sumber daya pertanian di desa berpotensi untuk dikembangkan. Salah satu system pertanian yang dikembangkan adalah minapadi yaitu suatu bentuk usaha tani gabungan (combined farming) yang memanfaatkan genangan air sawah menjadi kolam untuk budidaya ikan (jenis nila merah). Pengembangan Desa BSM yang berbasis agrowisata Minapadi ini merupakan implementasi tanggung jawab sosial dan lingkungan sebagai kontribusi untuk mencapai Sustainable Development Goals (SDGs), sekaligus merupakan bagian dari program pemberdayaan masyarakat.

14. Kelompok Sadar Wisata Kampung Minapadi Samberembe

Kelompok Sadar Wisata (Pokdarwis) Kampung Minapadi Samberembe yang dikukuhkan sejak tahun 2019 (setelah Peda-KTNA dilaksanakan di Samberembe) berperan penting terhadap pengembangan agrowisata minapadi di Samberembe. Pada tanggal 27 Januari 2021 agrowisata ini diresmikan menjadi "Mina Wisata Techno Park_Kampung Mina Padi Samberembe". Dengan adanya pokdarwis ini pengembanngan maupun pengelolaan agrowisata ini semakin tertata dan terarah.

Pokdarwis ini sebagai organisasi terstruktur dalam upaya pengembangan agrowisata. Pokdarwis ini sebagai syarat pengajuan suatu lokasi yang dikembangkan sebagai obyek wisata saat diajukan kepada pemerintah daerah. Dengan adanya pokdarwis ini pemerintah daerah juga akan lebih mudah dalam memberikan pendampingan, pelatihan maupun bantuan dana maupun hibah. Selain itu dengan adanya pokdarwis sebagai penanggung jawab pengelola suatu obyek wisata juga akan mempermudah saat mengajukan permohonan bantuan maupun kerjasama dengan pihak swasta.

Pokdarwis juga berperan dalam pengelolaan, promosi maupun inovasi dalam pengembangan agrowisata. Semakin inovatif dan solid personil pokdarwisnya maka semakin cepat pengembangan dan ide-ide pengembangan muncul. Semakin beragam destinasi maupun paket yang ditawarkan agrowista ini diharapkan mampu semakin menarik wisatawan untuk berkunjung ke agrowisata ini.

15. Kelompok Tani "Ngudi Lestari"

Kelompok tani "Ngudi Lestari" merupakan kelompok tani yang mengelola pertanian di Samberembe. Kelompok tani ini lebih fokus di pertaniannya yaitu di pengelolaan tanaman padi maupun hortikultura yang dikembangkan di Samberembe. Kelompok tani ini juga berperan penting dalam pengembangan agrowisata di Samberembe ini. 
Untuk pengelolaan pertanian di bawah koordinasi kelompok tani. Pengelolaan pertanian mina padi ini dilaksanakan secara bersama-sama (Kooperatif farming) sehingga membutuhkan coordinator, salah satunya kelompok tani ini. Dari mulai pra tanama hingga pasca panen pengelolaannya dikoordinasi oleh kelompok tani ini.

Kelompok tani ini juga mulai mengembangakan pengembangan pembudidayaan hortikultura yang idgabungkan dengan mina, seperti timun mina, cabai mina dan yang terakhir timun, bawang merah dan mina dalam 1 lahan sehingga ada 3 komoditas dalam 1 lahan. Pengembangan ke arah hortikulutura mina ini selain bertujuan untuk meningkatkan pendapatan petani juga sebagai salah satu daya tarik/ destinasi yang ditawarkan di agrowista minapadi Samberembe ini.

16. Kelompok Wanita Tani Samberembe

Kelompok wanita tani Samberembe merupakan kelompok tani yang beranggotakan petani wanita. Kelompok ini turut berperan juga dalam pengembangan agrowista minapadi Samberembe ini. Kelompok wanita tani ini berkolaborasi dengan kelompok tani Ngudi Rejeki dalam pengelolaan tanaman padi maupun hortikultura yang dibudidayakan di lokasi agrowisata minapadi Samberembe.

17. Kelompok Perikanan "Mina Muda"

Kelompok perikanan "Mina Muda" beranggotakan para petani yang menggeluti bidang pertanian perikanan. Pada dasarnya di Samberembe ini banyak petani yang berbasis di perikanan. Hal ini bernilai positif dalam pengembangan pertanian system minapadi karena lebih mudah dalam mengkoordinasikan mereka maupun dalam pengelolaan minapadi sendiri.

Kelompok perikanan ini berperan dalam pengelolaan ikan baik yang di lahan pertanian maupun di kolam. Kelompok perikanan berperan dalam pembudidsyaan ikan mulai dari penyediaan lahan, pembibitan, perawatan/pemeliharaan hingga panen dan pemasaran. Dengan adanya kelompok perikanan ini petani tidak akan kesulitan dan pemasaran hasil panen maupun tidak takut kalau tidak bisa menjual ikan setelah panen.

Perikanan ini menjadi destinasi yang menjadi salah satu daya tarik dari agrowisata minapadi ini. Penganjung dapat menikmati pemandangan ikan nila merah yang banyak berkumpul saat diberi makan (pengunjung dapat membeli makanan ikan dengan harga Rp $2.000,00$ /bungkus untuk bisa memberi makan ikan sendiri). Di agrowisata minapadi ini disediakan beberapa kolam untuk pemeliharaan ikan sebagai salah satu obyek yang ditawarkan.

18. Karang taruna Dusun Samberembe

Karang taruna Dususn Samberembe yang bernaggota pemuda dan pemudi di Samberembe dan kepala keluarga muda yang masih mau berkecimpung mengembangakan dusun melalui organisasi karang taruna. Karang taruna ini juga mempunyai peran dalam pengembangan agrowisata minapadi Samberembe ini. Para naggota ikut menyumbangkan tenaga maupun pikiran dalam pengembangan agrowista ini. Mereka turut bergotong royong maupun kerjabakti dalam penyiapan lahan untuk agrowisata maupun dalam penyiapan konsep agrowisata yang akan dikembangkan.

19. Poklahsar Mina Laras Mandiri Pakem

Poklahsar Mina Laras Mandiri Pakem beranggotakan ibu-ibu di Dusun Samberembe. Poklahsar ini turut berperan juga dalam pengembangan agrowisata minapadi ini. Polkahsar ini telah melakukan pengolahan hingga pemasaran dari produksi ikan nila. Produk olahan yang telah diproduksi polkahsar antara lain keripik baby nila, pepes nila, usaha catering, usaha angkringan, penyediaan menu makan untuk resto dengan menu utama ikan nila serta jasa membersihkan ikan nila sekaligus pemberian bumbu sehingga pembeli tinggal menggoreng atau memanggang ataupun diolah dalam bentuk lain. Dengan adanya usaha 
Pemetaan Stakeholder Yang Berperan Dalam Pengembangan Agrowisata Minapadi Samberembe Yhani Chrismawati, R Widodo Dwi Pramono

poklahsar ini pengunjung dapat menikmati pemandangan ataupun obyek lainnya yang ditawarkan sekaligus dapat menikmati kuliner maupun beli oleh-oleh dari agrowista ini.

Berikut ini disajikan tabel tentang pengaruh dan peran stakeholder dalam pengembangan agrowisata minapadi Samberembe untuk lebih memperjelas tentang peran masing-masing stakeholder.

Tabel 5 Pengaruh dan Peran Stakeholder dalam Pengembangan Agrowisata Minapadi Samberembe

\begin{tabular}{|c|c|c|c|c|c|}
\hline No & Stakeholder & Pengaruh & Kepentingan & Action & Resources \\
\hline 1 & $\begin{array}{l}\text { Kementerian } \\
\text { Kelautan dan } \\
\text { Perikanan } \\
\text { Republik } \\
\text { Indonesia }\end{array}$ & $\begin{array}{l}\text { - Memberikan } \\
\text { kontribusi yang } \\
\text { cukup besar untuk } \\
\text { pengadaan sarana } \\
\text { dan prasarana } \\
\text { budiadaya ikan } \\
\text { maupun } \\
\text { pengolahan ikan }\end{array}$ & $\begin{array}{l}\text { - Menyukseskan } \\
\text { program GEMARIKAN } \\
\text { (Gemar } \\
\text { Memasyarakatkan } \\
\text { Makan Ikan) sebagai } \\
\text { upaya peningkatan } \\
\text { gizi masyarakat sejak } \\
\text { dini } \\
\text { - Kebutuhan } \\
\text { masyarakat akan ikan } \\
\text { terpenuhi }\end{array}$ & $\begin{array}{l}\text { - Memberikan } \\
\text { bantuan berupa } \\
\text { mesin pakan } \\
\text { untuk program } \\
\text { pakan mandiri } \\
\text { dan paket } \\
\text { budidaya ikan } \\
\text { sistem bioflok, } \\
\text { kulkas frozen dan } \\
\text { mesin kincir air } \\
\text { serta } \\
\text { memberikan } \\
\text { pendampingan } \\
\text { dan pelatihan } \\
\text { teknis }\end{array}$ & $\begin{array}{l}\text { - Tersedianya } \\
\text { anggaran dana } \\
\text { untuk } \\
\text { pengembangan } \\
\text { usaha dalam } \\
\text { bidang perikanan } \\
\text { - Kemampuan } \\
\text { promosi }\end{array}$ \\
\hline 2 & $\begin{array}{l}\text { Dinas Pariwisata } \\
\text { DIY }\end{array}$ & $\begin{array}{l}\text { - Menyediakan } \\
\text { anggaran dana } \\
\text { untuk } \\
\text { pengembangan } \\
\text { usaha dalam } \\
\text { bidang pariwisata } \\
\text { - Kemampuan } \\
\text { promosi dan } \\
\text { menjalin } \\
\text { hubungan dengan } \\
\text { stakeholder lain } \\
\text { serta pelayanan } \\
\text { perijinan }\end{array}$ & $\begin{array}{l}\text { - Memajukan } \\
\text { pariwisata berbasis } \\
\text { potensi lokal } \\
\text { - Mengembangkan } \\
\text { potensi dan } \\
\text { sumberdaya lokal } \\
\text { untuk kesejahteraan } \\
\text { masyarakat }\end{array}$ & $\begin{array}{l}\text { - Memberikan } \\
\text { bantuan/hibah } \\
\text { berupa peralatan } \\
\text { yang berguna } \\
\text { untuk } \\
\text { pelaksanaan } \\
\text { protocol } \\
\text { kesehatan di } \\
\text { tempat umum } \\
\text { berupa wastafel, } \\
\text { masker, hand } \\
\text { sanitizer, vitamin }\end{array}$ & $\begin{array}{l}\text { - Tersedianya } \\
\text { anggaran dana } \\
\text { untuk mendukung } \\
\text { pengembangan } \\
\text { pariwisata (dana } \\
\text { hibah maupun } \\
\text { pelatihan) } \\
\text { - Pelayanan perijinan } \\
\text { - Kemampuan } \\
\text { promosi }\end{array}$ \\
\hline 3 & $\begin{array}{l}\text { Dinas Pariwisata } \\
\text { Kabupaten } \\
\text { Sleman }\end{array}$ & $\begin{array}{l}\text { - Instansi yang } \\
\text { langsung } \\
\text { membawahi } \\
\text { urusan pariwisata } \\
\text { - Berhak } \\
\text { menyediakan } \\
\text { anggaran dana } \\
\text { untuk } \\
\text { pendampingan } \\
\text { pengembangan } \\
\text { usaha dalam } \\
\text { bidang pariwisata } \\
\text { - Kemampuan } \\
\text { promosi dan } \\
\text { mrnjalin hubungan } \\
\text { dengan } \\
\text { stakeholder lain } \\
\text { serta pelayanan } \\
\text { perijinan }\end{array}$ & $\begin{array}{l}\text { - Memajukan } \\
\text { pariwisata berbasis } \\
\text { potensi lokal } \\
\text { - Mengembangkan } \\
\text { potensi dan } \\
\text { sumberdaya lokal } \\
\text { untuk kesejahteraan } \\
\text { masyarakat }\end{array}$ & $\begin{array}{l}\text { - Mengukuhkan } \\
\text { terbentuknya } \\
\text { pokdarwis } \\
\text { Samberembe } \\
\text { - Memberikan } \\
\text { bantuan/hibah } \\
\text { berupa } \\
\text { pembangunan } \\
\text { infrastruktur } \\
\text { agrowisata } \\
\text { - Melakukan } \\
\text { pelatihan dan } \\
\text { pendampingan }\end{array}$ & $\begin{array}{l}\text { - Tersedianya } \\
\text { anggaran dana } \\
\text { untuk mendukung } \\
\text { pengembangan } \\
\text { pariwisata (dana } \\
\text { hibah maupun } \\
\text { pelatihan dan } \\
\text { pendampingan) } \\
\text { - Pelayanan perijinan } \\
\text { - Kemampuan } \\
\text { promosi }\end{array}$ \\
\hline 4 & $\begin{array}{l}\text { Dinas Pertanian } \\
\text { dan Ketahanan } \\
\text { Pangan DIY }\end{array}$ & $\begin{array}{l}\text { - Mengkoordiansi } \\
\text { dinas pertanian di } \\
\text { kabupaten kota }\end{array}$ & $\begin{array}{l}\text { - Perlindungan LP2B } \\
\text { - Ketahanan Pangan }\end{array}$ & $\begin{array}{l}\text { - Memberikan } \\
\text { dukungan } \\
\text { pengembangan }\end{array}$ & $\begin{array}{l}\text { - Pelayanan perijinan } \\
\text { - Kemampuan } \\
\text { promosi }\end{array}$ \\
\hline
\end{tabular}


Pemetaan Stakeholder Yang Berperan Dalam Pengembangan Agrowisata Minapadi Samberembe Yhani Chrismawati, R Widodo Dwi Pramono

\begin{tabular}{|c|c|c|c|c|c|}
\hline No & Stakeholder & Pengaruh & Kepentingan & Action & Resources \\
\hline & & $\begin{array}{l}\text { untuk bidang } \\
\text { pertanian } \\
\text { - Melakukan oprasi } \\
\text { pasar terkait harga } \\
\text { bahan makanan } \\
\text { pokok }\end{array}$ & & $\begin{array}{l}\text { agrowisata } \\
\text { minapadi } \\
\text { terutama } \\
\text { pertanian } \\
\text { minapadi } \\
\text { maupun } \\
\text { minahorti }\end{array}$ & $\begin{array}{l}\text { - Kemampuan } \\
\text { pelatihan dan } \\
\text { pendampingan }\end{array}$ \\
\hline 5 & $\begin{array}{l}\text { Dinas Pertanian } \\
\text { Pangan dan } \\
\text { Perikanan } \\
\text { Kabupaten } \\
\text { Sleman }\end{array}$ & $\begin{array}{l}\text { - Memberi } \\
\text { dukungan material } \\
\text { dan semangat } \\
\text { untuk } \\
\text { pengembangan } \\
\text { agrowisata } \\
\text { minapadi } \\
\text { - Instansi yang } \\
\text { langsung terkait } \\
\text { dengan } \\
\text { pengelolaan } \\
\text { minapadi dan } \\
\text { pengembanganya }\end{array}$ & $\begin{array}{l}\text { - Meningkatkan } \\
\text { pendapatan } \\
\text { masyarakat } \\
\text { - Perlindungan LP2B } \\
\text { - Ketahanan pangan }\end{array}$ & $\begin{array}{l}\text { - Memberi } \\
\text { dukungan } \\
\text { pengembangan } \\
\text { agrowisata } \\
\text { minapadi melalui } \\
\text { pendampingan } \\
\text { dan legalitas } \\
\text { proposal yang } \\
\text { akan diajukan } \\
\text { - Memberi } \\
\text { bantuan } \\
\text { pembuatan } \\
\text { masterplan } \\
\text { agrowisata } \\
\text { minapadi }\end{array}$ & $\begin{array}{l}\text { - Pelayanan perijinan } \\
\text { - Kemampuan } \\
\text { promosi } \\
\text { - Kemampuan } \\
\text { pelatihan dan } \\
\text { pendampingan }\end{array}$ \\
\hline 6 & $\begin{array}{l}\text { Dinas Kelautan } \\
\text { dan Perikanan } \\
\text { DIY }\end{array}$ & $\begin{array}{l}\text { - Mengkoordinasi } \\
\text { dinas kelautan dan } \\
\text { perikanan di } \\
\text { tingkat kabupaten } \\
\text { - Pembuatan } \\
\text { program } \\
\text { pengembangan } \\
\text { sektor perikanan } \\
\text { disesuaikan } \\
\text { dengan }\end{array}$ & $\begin{array}{l}\text { - Menyukseskan } \\
\text { program GEMARIKAN } \\
\text { (Gemar } \\
\text { Memasyarakatkan } \\
\text { Makan Ikan) sebagai } \\
\text { upaya peningkatan } \\
\text { gizi masyarakat sejak } \\
\text { dini } \\
\text { - Kebutuhan } \\
\text { masyarakat akan ikan } \\
\text { terpenuhi }\end{array}$ & $\begin{array}{l}\text { - Berpartisipasi } \\
\text { dalan tahapan } \\
\text { pengembangan } \\
\text { agrowisota } \\
\text { - Melakukan } \\
\text { penndampingan } \\
\text { pengelolaan } \\
\text { minapadi } \\
\text { (terutama } \\
\text { budidaya ikan) }\end{array}$ & $\begin{array}{l}\text { - Pelayanan perijinan } \\
\text { - Kemampuan } \\
\text { promosi } \\
\text { - Kemampuan } \\
\text { pelatihan dan } \\
\text { pendampingan }\end{array}$ \\
\hline 7 & $\begin{array}{l}\text { Bappeda } \\
\text { Kabupaten } \\
\text { Sleman }\end{array}$ & $\begin{array}{l}\text { - Merencanakan } \\
\text { pengembangan } \\
\text { wilayah dengan } \\
\text { melibatkan } \\
\text { berbagai sektor } \\
\text { hingga tahap } \\
\text { monitoring } \\
\text { evaluasi }\end{array}$ & $\begin{array}{l}\text { - Memajukan wilayah } \\
\text { - Membuka lapangan } \\
\text { pekerjaan } \\
\text { - Perlindungan LP2B }\end{array}$ & $\begin{array}{l}\text { - Memberi } \\
\text { dukungan } \\
\text { pengembangan } \\
\text { agrowisata } \\
\text { melalui } \\
\text { pendampingan }\end{array}$ & $\begin{array}{l}\text { - Tersedianya } \\
\text { anggaran dana } \\
\text { untuk mendukung } \\
\text { pengembangan } \\
\text { wilayah } \\
\text { - Kemampuan } \\
\text { promosi } \\
\text { - Berhak menyusun } \\
\text { perencanaan } \\
\text { wilayah sesuai } \\
\text { RTRW }\end{array}$ \\
\hline 8 & $\begin{array}{l}\text { Dinas } \\
\text { Pertanahan dan } \\
\text { Tata Ruang } \\
\text { Kabupaten } \\
\text { Sleman }\end{array}$ & $\begin{array}{l}\text { - Berhak } \\
\text { memberikan ijin } \\
\text { lokasi untuk } \\
\text { pengembangan } \\
\text { agrowisata jika } \\
\text { sesuai dengan } \\
\text { arahan RTRW } \\
\text { Kabipaten Sleman }\end{array}$ & $\begin{array}{l}\text { - Memajukan wilayah } \\
\text { - Membuka lapangan } \\
\text { pekerjaan } \\
\text { - Perlindungan LP2B }\end{array}$ & $\begin{array}{l}\text { - Memberi } \\
\text { dukungan } \\
\text { pengembangan } \\
\text { agrowisata }\end{array}$ & $\begin{array}{l}\text { - Memberikan ijin } \\
\text { kepada unit usaha } \\
\text { agrowisata sesuai } \\
\text { arahan dan } \\
\text { rencana Tata } \\
\text { Ruang Provinsi }\end{array}$ \\
\hline 9 & $\begin{array}{l}\text { Pemerintah } \\
\text { Kapanewon } \\
\text { Pakem }\end{array}$ & $\begin{array}{l}\text { - Instansi yang } \\
\text { berhak } \\
\text { memberikan } \\
\text { legalitas perijinan } \\
\text { kegiatan maupun }\end{array}$ & $\begin{array}{l}\text { - Memajukan wilayah } \\
\text { - Membuka lapangan } \\
\text { pekerjaan } \\
\text { - Meningkatkan } \\
\text { pendapatan } \\
\text { masyarakat }\end{array}$ & $\begin{array}{l}\text { - Memberikan } \\
\text { dukungan dan } \\
\text { perijinan } \\
\text { pembangunan } \\
\text { agrowisata }\end{array}$ & $\begin{array}{l}\text { - Pemangku } \\
\text { kebijakan } \\
\text { - Pelayanan dan } \\
\text { perijinan } \\
\text { - Promosi }\end{array}$ \\
\hline
\end{tabular}


Pemetaan Stakeholder Yang Berperan Dalam Pengembangan Agrowisata Minapadi Samberembe Yhani Chrismawati, R Widodo Dwi Pramono

\begin{tabular}{|c|c|c|c|c|c|}
\hline No & Stakeholder & Pengaruh & Kepentingan & Action & Resources \\
\hline & & $\begin{array}{l}\text { pengajuan } \\
\text { proposal } \\
\text { - Berhak } \\
\text { memberikan } \\
\text { bantuan dana } \\
\text { pengembangan } \\
\text { agrowisata } \\
\text { maupun pelatihan }\end{array}$ & - Perlindungan LP2B & $\begin{array}{l}\text { - Memberikan } \\
\text { pengesahan ijin } \\
\text { ataupun } \\
\text { proposal } \\
\text { pokdarwis } \\
\text { agrowisata } \\
\text { minapadi }\end{array}$ & $\begin{array}{l}\text { - Penyedia data dan } \\
\text { Informasi } \\
\text { - Pemberdayaan } \\
\text { masysrakat }\end{array}$ \\
\hline 10 & $\begin{array}{l}\text { Pemerintah } \\
\text { Desa } \\
\text { Candibinangun }\end{array}$ & $\begin{array}{l}\text { - Instansi terendah } \\
\text { yang berhak } \\
\text { memberikan } \\
\text { legalitas perijinan } \\
\text { kegiatan maupun } \\
\text { pengajuan } \\
\text { proposal } \\
\text { - Berhak } \\
\text { memberikan } \\
\text { bantuan dana } \\
\text { pengembangan } \\
\text { agrowisata } \\
\text { maupun pelatihan }\end{array}$ & $\begin{array}{l}\text { - Memajukan wilayah } \\
\text { - Membuka lapangan } \\
\text { pekerjaan } \\
\text { - Meningkatkan } \\
\text { pendapatan } \\
\text { masyarakat } \\
\text { - Perlindungan LP2B }\end{array}$ & $\begin{array}{l}\text { - Memberikan } \\
\text { dukungan dan } \\
\text { perijinan } \\
\text { pembangunan } \\
\text { agrowisata } \\
\text { - Memberikan } \\
\text { pengesahan ijin } \\
\text { ataupun } \\
\text { proposal } \\
\text { pokdarwis } \\
\text { agrowisata } \\
\text { minapadi }\end{array}$ & $\begin{array}{l}\text { - Pemangku } \\
\text { kebijakan } \\
\text { - Pelayanan dan } \\
\text { perijinan } \\
\text { - Promosi } \\
\text { - Penyedia data dan } \\
\text { Informasi } \\
\text { - Pemberdayaan } \\
\text { masysrakat }\end{array}$ \\
\hline 11 & $\begin{array}{l}\text { Bank Rakyat } \\
\text { Indonesia }\end{array}$ & $\begin{array}{l}\text { - Mempermudah } \\
\text { dalam penyediaan } \\
\text { dana melalui } \\
\text { pinjaman KUR }\end{array}$ & $\begin{array}{l}\text { - Usaha mikro dan } \\
\text { menengah dalam } \\
\text { berkembang } \\
\text { sehingga } \\
\text { kesejahteraan } \\
\text { masyarakat } \\
\text { meningkat. }\end{array}$ & $\begin{array}{l}\text { - Menyetujui } \\
\text { pengajuan KUR } \\
\text { dan } \\
\text { mengucurkan } \\
\text { dana untuk } \\
\text { pengembangan } \\
\text { agrowisata } \\
\text { minapadi } \\
\text { Samberembe }\end{array}$ & $\begin{array}{l}\text { - Modal untuk } \\
\text { dipinjamkan untuk } \\
\text { pengembangan } \\
\text { usaha dengan } \\
\text { bunga rendah } \\
\text { (KUR) }\end{array}$ \\
\hline 12 & $\begin{array}{l}\text { Bank } \\
\text { Pembangunan } \\
\text { Daerah }\end{array}$ & $\begin{array}{l}\text { - Memberikan hibah } \\
\text { untuk } \\
\text { pembangunan } \\
\text { infrastruktur, } \\
\text { pelatihan dan } \\
\text { pendampingan } \\
\text { dan promosi }\end{array}$ & $\begin{array}{l}\text { - Memajukan wilayah } \\
\text { dan meningkatkan } \\
\text { PAD melalui } \\
\text { pengembangan } \\
\text { agrowisata maupun } \\
\text { pemberian kredit } \\
\text { usaha }\end{array}$ & $\begin{array}{l}\text { - Memberikan } \\
\text { bantuan } \\
\text { dana/hibah dana } \\
\text { yang diwujudkan } \\
\text { pembangunan } \\
\text { infrstruktur dan } \\
\text { pendampingan } \\
\text { untuk } \\
\text { pengembangan } \\
\text { agrowisata } \\
\text { minapadi } \\
\text { Samberembe }\end{array}$ & $\begin{array}{l}\text { - Modal untuk } \\
\text { dipinjamkan untuk } \\
\text { pengembangan } \\
\text { usaha dengan } \\
\text { bunga rendah } \\
\text { - Ada program } \\
\text { bantuan danadan } \\
\text { pendampingan } \\
\text { untuk } \\
\text { pengembangan } \\
\text { usaha }\end{array}$ \\
\hline 13 & $\begin{array}{l}\text { Rumah Zakat, } \\
\text { Laznas BSM dan } \\
\text { Bank mandiri } \\
\text { Syariah }\end{array}$ & $\begin{array}{l}\text { - Memberikan hibah } \\
\text { yang cukup besar } \\
\text { untuk } \\
\text { pembangunan } \\
\text { infrastruktur dan } \\
\text { pengadaaan } \\
\text { sarana prasarana } \\
\text { pengembangan } \\
\text { agrowisata } \\
\text { minapadi } \\
\text { - Menyediakan } \\
\text { fasilitas pelatihan } \\
\text { dan } \\
\text { pendampingan }\end{array}$ & $\begin{array}{l}\text { - Memajukan wilayah } \\
\text { dengan } \\
\text { mengembangkan } \\
\text { pogtensi sefrta } \\
\text { sumberdaya serta } \\
\text { pemberdayaan } \\
\text { masysrakat melalui } \\
\text { pengembangan Desa } \\
\text { Berdaya Sejahtera } \\
\text { Mandiri (BSM) }\end{array}$ & $\begin{array}{l}\text { - Memberikan } \\
\text { bantuan berupa } \\
\text { benih, } \\
\text { - Melakukan } \\
\text { pendampingan } \\
\text { - Pengadaan } \\
\text { sarana dan } \\
\text { prasarana } \\
\text { - Pembangunan } \\
\text { infrastruktur } \\
\text { sebesar Rp } \\
\text { 500.000.000,- } \\
\text { - yang pengelolaan } \\
\text { uangnya }\end{array}$ & $\begin{array}{l}\text { - Tersedia dana yang } \\
\text { cukup besar dan } \\
\text { pendampingan } \\
\text { untuk } \\
\text { pengembangan } \\
\text { potensi dan } \\
\text { sumberdaya } \\
\text { daerah sekaligus } \\
\text { pemberdayaan } \\
\text { masyarakat }\end{array}$ \\
\hline
\end{tabular}




\begin{tabular}{|c|c|c|c|c|c|}
\hline No & Stakeholder & Pengaruh & Kepentingan & Action & Resources \\
\hline & & $\begin{array}{l}\text { - Melakukan } \\
\text { promosi }\end{array}$ & & $\begin{array}{l}\text { dilkaukan oleh } \\
\text { rumah zakat }\end{array}$ & \\
\hline 14 & $\begin{array}{l}\text { Kelompok Sadar } \\
\text { Wisata } \\
\text { Kampung } \\
\text { Minapadi } \\
\text { Samberembe }\end{array}$ & $\begin{array}{l}\text { - Menginisiasi } \\
\text { dikembangkannny } \\
\text { a agrowisata } \\
\text { minapadi } \\
\text { Samberembe. } \\
\text { Tanpa adanya } \\
\text { pokdarwis ini } \\
\text { agrowisata } \\
\text { minapadi belum } \\
\text { tentu } \\
\text { dikembangkan } \\
\text { - Mediator dan } \\
\text { fasilitator } \\
\text { mengajukan } \\
\text { berbagai proposal } \\
\text { ke dinas dan } \\
\text { stakeholder terkait } \\
\text { - Menyusun } \\
\text { rencana } \\
\text { pengembangan } \\
\text { agrowisata ke } \\
\text { depannya } \\
\text { Menyusun paket- } \\
\text { paket yang } \\
\text { ditawarkan dalam } \\
\text { agrowisata dan } \\
\text { mempromosikann } \\
\text { ya }\end{array}$ & $\begin{array}{l}\text { - Memajukan wilayah } \\
\text { - Membuka lapangan } \\
\text { - Mekerjaan } \\
\text { kenambah } \\
\text { keterampilan/kemam } \\
\text { - Muan pengelolaan } \\
\text { - Meningkatkan } \\
\text { - Pendapatan } \\
\text { Perlindungan LP2B }\end{array}$ & $\begin{array}{l}\text { - Inisiator } \\
\text { dikembangkannn } \\
\text { ya agrowisata } \\
\text { minapadi } \\
\text { Samberembe } \\
\text { - Mengajukan } \\
\text { proposal } \\
\text { bantuan maupun } \\
\text { promosi } \\
\text { agrowisata ke } \\
\text { dinas maupun } \\
\text { stakeholder } \\
\text { terkait } \\
\text { - Menemukan } \\
\text { inovasi baru } \\
\text { untuk } \\
\text { pengembangan } \\
\text { agrowisata } \\
\text { - Ikut terlibat } \\
\text { dalam tahapan } \\
\text { pengembangan } \\
\text { agrowisata }\end{array}$ & $\begin{array}{l}\text { - Organisasi yang } \\
\text { aktif } \\
\text { - Anggota dan } \\
\text { pengurus yang aktif } \\
\text { - Inisiator, inovator } \\
\text { dan pengelola yang } \\
\text { bertanggung jawab } \\
\text { tentang agrowisata } \\
\text { - Mempunyai chanel } \\
\text { di bidang } \\
\text { pariwisata } \\
\text { - Kemampuan } \\
\text { pengelola dalam } \\
\text { pelayanan terkait } \\
\text { agrowisata, } \\
\text { komunikasi, } \\
\text { promosi maupun } \\
\text { negosiasi dengan } \\
\text { stakeholder terkait }\end{array}$ \\
\hline 15 & $\begin{array}{l}\text { Kelompok Tani } \\
\text { "Ngudi Lestari" }\end{array}$ & $\begin{array}{l}\text { Berkolaborasi } \\
\text { dengan kelompok } \\
\text { perikanan :Mina } \\
\text { Muda" : } \\
\text { - Menginisiasi } \\
\text { dikembangkannny } \\
\text { a pertanian } \\
\text { minapadi } \\
\text { Samberembe. } \\
\text { - Mediator dan } \\
\text { fasilitator } \\
\text { mengajukan } \\
\text { berbagai proposal } \\
\text { ke dinas dan } \\
\text { stakeholder terkait } \\
\text { - Mengkoordinir } \\
\text { pelaksanaan } \\
\text { system } \\
\text { pengelolaan } \\
\text { pertanian } \\
\text { minapadi melalui } \\
\text { "kooperatif } \\
\text { farming" }\end{array}$ & $\begin{array}{l}\text { - Memajukan wilayah } \\
\text { - Membuka lapangan } \\
\text { pekerjaan } \\
\text { - Menambah } \\
\text { keterampilan/kemam } \\
\text { puan pengelolaan } \\
\text { - Meningkatkan } \\
\text { pendapatan } \\
\text { - Perlindungan LP2B }\end{array}$ & $\begin{array}{l}\text { Pengelolaan } \\
\text { pertanian } \\
\text { minapadi (khusus } \\
\text { pada pertanian } \\
\text { padi atau } \\
\text { hortikultura) dari } \\
\text { mulai masa pra } \\
\text { tanam hingga } \\
\text { pasca panen } \\
\text { dengan system } \\
\text { pengelolaan } \\
\text { "kooperatif } \\
\text { farming" } \\
\text { - Ikut terlibat } \\
\text { dalam tahapan } \\
\text { pengembangan } \\
\text { agrowisata }\end{array}$ & $\begin{array}{l}\text { - Organisasi yang } \\
\text { aktif } \\
\text { - Anggota dan } \\
\text { pengurus yang aktif } \\
\text { - Pengelola } \\
\text { pertanian } \\
\text { - Inisiator dan } \\
\text { innovator } \\
\text { pertanian } \\
\text { - Kemampuan } \\
\text { pengelola dalam } \\
\text { pelayanan terkait } \\
\text { agrowisata, } \\
\text { komunikasi, } \\
\text { promosi maupun } \\
\text { negosiasi dengan } \\
\text { stakeholder terkait } \\
\text { - Kemampuan } \\
\text { pengelola dalam } \\
\text { pelayanan terkait } \\
\text { pertanian, } \\
\text { komunikasi, } \\
\text { promosi maupun } \\
\text { negosiasi dengan } \\
\text { stakeholder terkait }\end{array}$ \\
\hline 16 & $\begin{array}{l}\text { Kelompok } \\
\text { Wanita Tani } \\
\text { Samberembe }\end{array}$ & $\begin{array}{l}\text { - Berpartisipasi } \\
\text { dalam pengelolaan } \\
\text { pertanian } \\
\text { minapadi maupun } \\
\text { pengembangan }\end{array}$ & $\begin{array}{l}\text { - Membuka lapangan } \\
\text { pekerjaan } \\
\text { - Menambah } \\
\text { keterampilan/kemam } \\
\text { puan pengelolaan }\end{array}$ & $\begin{array}{l}\text { - } \text { Turut } \\
\text { berpartisiapsi } \\
\text { dalam } \\
\text { pengelolaan } \\
\text { tanaman padi }\end{array}$ & - SDM \\
\hline
\end{tabular}


Pemetaan Stakeholder Yang Berperan Dalam Pengembangan Agrowisata Minapadi Samberembe Yhani Chrismawati, R Widodo Dwi Pramono

\begin{tabular}{|c|c|c|c|c|c|}
\hline No & Stakeholder & Pengaruh & Kepentingan & Action & Resources \\
\hline & & $\begin{array}{l}\text { agrowisata } \\
\text { minapadi }\end{array}$ & $\begin{array}{l}\text { - Meningkatkan } \\
\text { pendapatan }\end{array}$ & $\begin{array}{l}\text { maupun } \\
\text { hortikultura } \\
\text { - Ikut terlibat } \\
\text { dalam tahapan } \\
\text { pengembangan } \\
\text { agrowisata }\end{array}$ & \\
\hline 17 & $\begin{array}{l}\text { Kelompok } \\
\text { Perikanan } \\
\text { "Mina Muda" }\end{array}$ & $\begin{array}{l}\text { Kolaborasi dengan } \\
\text { kelompok tani “ } \\
\text { Ngudi Lestari” : } \\
\text { - menginisiasi } \\
\text { dikembangkannny } \\
\text { a pertanian } \\
\text { minapadi } \\
\text { Samberembe. } \\
\text { - Mediator dan } \\
\text { fasilitator } \\
\text { mengajukan } \\
\text { berbagai proposal } \\
\text { ke dinas dan } \\
\text { stakeholder terkait } \\
\text { - Mengkoordinir } \\
\text { pelaksanaan } \\
\text { system } \\
\text { pengelolaan } \\
\text { pertanian } \\
\text { minapadi melalui } \\
\text { "kooperatif } \\
\text { farming” }\end{array}$ & $\begin{array}{l}\text { - Memajukan wilayah } \\
\text { - Membuka lapangan } \\
\text { pekerjaan } \\
\text { - Menambah } \\
\text { keterampilan/kemam } \\
\text { puan pengelolaan } \\
\text { - Meningkatkan } \\
\text { pendapatan } \\
\text { - Perlindungan LP2B }\end{array}$ & $\begin{array}{l}\text { - Pengelolaan } \\
\text { perikanan secara } \\
\text { kelompok baik } \\
\text { yang dipeliharan } \\
\text { di kolam maupun } \\
\text { sawah (di } \\
\text { kawasan } \\
\text { agrowisata) } \\
\text { mulai dari } \\
\text { penyediaan } \\
\text { lahan, } \\
\text { pembibitan, } \\
\text { perawatan, } \\
\text { panen hingga } \\
\text { pemasaran } \\
\text { - Ikut terlibat } \\
\text { dalam tahapan } \\
\text { pengembangan } \\
\text { agrowisata }\end{array}$ & $\begin{array}{l}\text { - Organisasi yang } \\
\text { aktif } \\
\text { - Anggota dan } \\
\text { pengurus yang aktif } \\
\text { - Pengelola } \\
\text { perikanan } \\
\text { - Inisiator perikanan } \\
\text { - Kemampuan } \\
\text { pengelola dalam } \\
\text { pelayanan terkait } \\
\text { perikanan, } \\
\text { komunikasi, } \\
\text { promosi maupun } \\
\text { negosiasi dengan } \\
\text { stakeholder terkait }\end{array}$ \\
\hline 18 & $\begin{array}{l}\text { Karang Taruna } \\
\text { Dusun } \\
\text { Samberembe }\end{array}$ & $\begin{array}{l}\text { - Berpartisipasi } \\
\text { dalam persiapan } \\
\text { dan } \\
\text { pengembangan } \\
\text { agrowisata } \\
\text { minapadi }\end{array}$ & $\begin{array}{l}\text { - Membuka lapangan } \\
\text { pekerjaan } \\
\text { - Menambah } \\
\text { keterampilan/kemam } \\
\text { puan pengelolaan } \\
\text { - Meningkatkan } \\
\text { pendapatan }\end{array}$ & $\begin{array}{l}\text { - Melakukan } \\
\text { gotong royong } \\
\text { dan kerjabakti } \\
\text { dalam } \\
\text { menyiapakan } \\
\text { lahan untuk } \\
\text { agrowisata } \\
\text { - Ikut terlibat } \\
\text { dalam tahapan } \\
\text { pengembangan } \\
\text { agrowisata } \\
\text { - Menyumbangkan } \\
\text { ide dalam rangka } \\
\text { penyiapan } \\
\text { konsep } \\
\text { agrowisata } \\
\text { - Ikut terlibat } \\
\text { dalam tahapan } \\
\text { pengembangan } \\
\text { agrowisata }\end{array}$ & $\begin{array}{l}\text { - SDM } \\
\text { - Tenaga } \\
\text { - Pikiran, ide }\end{array}$ \\
\hline 19 & $\begin{array}{l}\text { Poklahsar Mina } \\
\text { Laras Mandiri } \\
\text { Pakem }\end{array}$ & $\begin{array}{l}\text { - Berpartisipasi } \\
\text { dalam pengolahan } \\
\text { dan pemasaran } \\
\text { hasil panen ikan } \\
\text { serta } \\
\text { pengembangan } \\
\text { agrowisata } \\
\text { minapadi } \\
\text { terkhusus untuk } \\
\text { pengembangan di } \\
\text { bidang kuliner }\end{array}$ & $\begin{array}{l}\text { - Membuka lapangan } \\
\text { pekerjaan } \\
\text { - Menambah } \\
\text { keterampilan/kemam } \\
\text { puan pengelolaan } \\
\text { - Meningkatkan } \\
\text { pendapatan }\end{array}$ & $\begin{array}{l}\text { - Melakukan } \\
\text { pengolahan dan } \\
\text { pemasaran } \\
\text { produk ikan nila } \\
\text { - Mengelola usaha } \\
\text { kuliner dan } \\
\text { angkringan di } \\
\text { agrowisata } \\
\text { minapadi } \\
\text { Samberembe }\end{array}$ & $\begin{array}{l}\text { - SDM } \\
\text { - Keterampilan/ } \\
\text { kreasi memasak } \\
\text { - Jaringan } \\
\text { pemasaran }\end{array}$ \\
\hline
\end{tabular}




\begin{tabular}{|c|c|c|c|c|c|}
\hline No & Stakeholder & Pengaruh & Kepentingan & Action & Resources \\
\hline & & & & $\begin{array}{l}\text { - Ikut terlibat } \\
\text { dalam tahapan } \\
\text { pengembangan } \\
\text { agrowisata }\end{array}$ & \\
\hline
\end{tabular}

Sumber : hasil Analisis, 2021

\section{Pemetaan Peran Stakeholder dalam Pengembangan Agrowisata Minapadi}

Pemetaan stakeholder dalam pengembangan agrowisata minapadi Samberembe didasarkan pada tingkat kepentingan dan pengaruh stakeholder dalam pengembangan agrowisata minapadi. Tingkat kepentingan stakeholder diukur menggunakan 4 indikator, sedangkan tingkat pengaruh stakeholder diukur dengan menggunakan 3 indikator. Kemudian menggunakan matriks kepentingan dan pengaruh stakeholder pemberian skoring dilakukan tethadap setiap stakeholder sesuai action yang dilakukan dalam pengembanagn agrowisata minapadi. Hal ini untuk mengukur tingkat pengaruh dan kepentingan stakeholder dalam pengembangan agrowisata minapadi Samberembe.

Berdasarkan hasil analisis data (perolehan skor setiap stakeholder dalam penilaian setiap kriteria) dapat diketahui bahwa stakeholder dalam pengembangan agrowisata minapadi Samberembe berdasarkan tingkat kepentingan dan tingkat pengaruh dapat dibagi menjadi 4 kategori yaitu :

(1) Stakeholder dengan tingkat kepentingan tinggi dan tingkat pengaruh besar (pemain kinci/key players)

Untuk stakeholder dengan tingkat kepentingan tinggi dan tingkat pengaruh besar terdiri dari Dinas Pertanian Pangan dan Perikanan Kabupaten Sleman, dinas Pariwisata Kabupaten Sleman, Kelompok Sadar Wisata Kampung Minapadi Samberembe, Kelompok Tani "Ngudi Lestari" dan Kelompok perikanan "Mina Muda".

(2) Stakeholder dengan tingkat kepentingan tinggi dan tingkat pengaruh kecil (subyek/subjects)

Stakeholder dengan tingkat kepentingan tinggi dan tingkat pengaruh kecil terdiri dari kelompok Wanita Tani Samberembe, Karang taruna Dusun Samberembe dan Poklahsar Mina laras Mandiri Pakem. Stakeholder ini mempunyai kepentingan yang tinggi terhadap keberhasilan pengembangan agrowisata minapadi Samberembe namun pengaruh mereka tergolong kecil dalam pengembangan agrowisata ini.

(3) Stakeholder dengan tingkat kepentingan rendah dan tingkat pengaruh besar (pendukung/contest setter)

Stakeholder yang memiliki tingkat kepentingan kecil dan tingkat pengaruh besar adalah Kementerian kelautan dan Perikanan Republik Indonesia, Dinas Pariwisata DIY dan Rumah Zakat, Laznaz BSM dan Bank Mandiri Syariah. Stakeholder ini mempunyai tingkat pengaruh besar terutama dalam penyediaan anggaran dana dalam pengembangan agrowisata minapadi Samberembe baik ungtuk pembangunan infrastruktur maupun untuk pendampingan dan pelatihan SDM dalam rangka pengeambangan agrowisata minapadi.

(4) Stakeholder dengan tingkat kepentingan rendah dan tingkat pengaruh kecil (pengikut lain/crowd)

Stakeholder dengan tingkat kepentingan rendah dan tingkat pengaruh kecil terdiri dari Dinas Pertanian dan Ketahanan Pangan DIY, Bappeda kabupaten Sleman, Dinas pertanahan dan tata ruang Kabupaten Sleman, Dinas kelautan dan Perikanan DIY, Pemerintah Kapanewon Pakem, Pemerintah Desa Candibinangun, Bank Rakyat Indonesia, dan Bank Pembangunan Daerah.

Untuk lebih jelasnya pembagian stakeholder dalam pengembangan agrowisata minapadi Samberembe dapat dilihat dalam matriks pemetaan stakeholder pada Tabel 6. 
Pemetaan Stakeholder Yang Berperan Dalam Pengembangan Agrowisata Minapadi Samberembe Yhani Chrismawati, R Widodo Dwi Pramono

Tabel 6 Matriks Kepentingan dan Pengaruh Stakeholder dalam Pengembangan Agrowisata Minapadi Samberembe

Pengaruh Besar

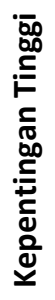
Kabupaten Sleman
1. Dinas Pertanian Pangan dan Perikanan

2. Dinas Pariwisata Kabupaten Sleman

3. Kelompok sadar Wisata kampung minapadi Samberembe

4. Kelompok Tani "Ngudi Lestari"

5. Kelompok Perikanan "Mina Muda"

1. Kementerian Kelautan dan Perikanan Republik Indonesia

2. Dinas Pariwisata DIY

3. Rumah Zakat, Laznas BSM dan Bank Mandiri Syariah

\section{Pengaruh Kecil}

1. Kelompok Wanita Tani Samberembe

2. Karang Taruna Dusun Samberembe

3. Poklahsar Mina Laras Mandiri akem

1. Dinas Pertanian dan Ketahanan Pangan DIY

2. Bappeda Kabupaten Sleman

3. Dinas pertanahan dan tata ruang Kabupaten Sleman

4. Dinas Kelautan dan Perikanan DIY

5. Pemerintah Kapanewon Pakem

6. Pemerintah Desa Candibinangun

7. Bank Rakyat Indonesia

8. Bank Pembangunan Daerah

Sumber : Hasil analisis (2021)

Berdasarkan hasil analisis stakeholder mapping yang dilakukan dapat diketahui bahwa keberhasilan dari kolaborasi stakeholder sangat mendukung pengembangan kegiatan ekonomi yang berbasis potensi lokal. Kolaborasi antara pemerintah pusat, pemerintah daerah, masyarakat dan swasta yang telah terbentuk sejak di pertengahan tahun 2019 (agrowisata minapadi dirintis), hal ini memudahkan komunikasi antar stakeholder. Masing-masing stakeholder terlibat sesuai perannya dan tupoksinya masing-masing. Pemerintah pusat dan daerah selaku pemangku kebijakan berhak memberikan perizinan maupun hibah dan melakukan pendampingan, swasta bertindak pemberi hibah dana pembangunan dan masyarakat sebagai pengelola pertanian dan agrowisata minapadi.

Dukungan dari masyarakat memiliki porsi yang besar juga dalam menentukan keberhasilan pengembangan agrowisata minapadi Samberembe. Terutama masyarakat yang berperan sebagai local champion (tokoh lokal) selaku inisiator, fasilitator dan mobilisator dalam pengembangan agrowisata ini. Dukungan masyarakat melalui peran aktifnya dalam kelompok tani, kelompok ikan, poklahsar, karang taruna, kelompok wanita tani dan pokdarwis juga mendukung keberhasilan pengembangan agrowisata ini karena sekarang ini pengelolalan pertanian, perikanan dan agrowisata dikelola secara kelompok. Terutama dalam pengelolaan pertanian minapadi dikelola secara "kooperatif farming" yaitu pengelolaan lahan pertanian secara kelompok (bukan lagi individual pemilik lahan) dari mulai masa pra tanam hingga pasca panen. Setiap kelompok sudah mempunyai Standar Operasional Prosedur (SOP) masingmasing.

\section{KESIMPULAN}


Agrowisata minapadi Samberembe merupakan bentuk pengembangan kegiatan ekonomi berbasis potensi lokal yang bertujuan meningkatkan pendapatan masyarakat sekaligus untuk mempertahankan lahan pertanian dengan pengelolaan yang terintegrasi dan dilakukan secara cooperative farming. Agrowisata ini dapat dikatakan sebagai salah satu solusi dalam upaya konservasi lahan pertanian. Untuk dapat mengembangkan agrowisata minapadi Samberembe ini diperlukan dukungan dari berbagai stakeholder dengan perannnya masing-masing. Stakeholder yang paling berpengaruh terutama tokoh kunci (key players), peran masyarakat terutama local champion dan keberhasilan kolaborasi antar stakeholder.

\section{REKOMENDASI}

1. Untuk melestarikan LP2B di Kabupaten Sleman diperlukan upaya sosialiasi terkait LP2B serta pertanian integratif (minapadi) ke setiap kecamatan di Kabupaten Sleman.

2. Pemerintah mendukung adanya proyek replikasi agrowisata minapadi samberembe ini di kecamatan lain dalam upaya konservasi LP2B.

3. Perlunya pemerintah membuat program studi banding ke wialyah lain yang berhasil mengembangkan pertanian integratif maupun agrowisata.

4. Perlunya membangkitkan local champion maupun meningkatkan kolaborasi stakeholder dalam mengembangkan kegiatan ekonomi berbasis potensi lokal.

\section{UCAPAN TERIMAKASIH}

Terimakasih kepada petani, kelompok tani, pokdarwis dan segenap pengelola kawasan agrowisata minapadi Samberembe, dan pihak-pihak yang telah membantu terselesaikannya penelitian.

\section{DAFTAR PUSTAKA}

Aprita, A. (2019, Maret 29). Banyak Dijadikan Pemukiman, Penyusutan Lahan Pertanian di Sleman Capai 100 Hektare Pertahun. Retrieved April 6, 2020, from Banyak Dijadikan Pemukiman, Penyusutan Lahan Pertanian di Sleman Capai 100 Hektare Pertahun: https://jogja.tribunnews.com/2019/03/29/banyak-dijadikan-pemukiman-penyusutanlahan-pertanian-di-sleman-capai-100-hektare-pertahun.

Ashari. (2013). Tinjauan Tentang Alih Fungsi Lahan Sawah ke Non Sawah dan Dampaknya di Pulau Jawa. Forum penelitian Agro Ekonomi, Vol.21 No.2 (83-98).

BPS - Statistics of D.I. Yogyakarta Province. (2013). Daerah Istimewa Yogyakarta Dalam Angka 2013. Yogyakarta: BPS - Statistics of D.I. Yogyakarta Province.

BPS - Statistics of D.I. Yogyakarta Province. (2017). Daerah Istimewa Yogyakarta Dalam Angka 2017. BPS - Statistics of D.I. Yogyakarta Province.

BPS-Statistics Indonesia. (2017). Statistik Indonesia 2017. Jakarta: BPS-Statistics Indonesia.

BPS-Statistics Indonesia. (2019). Statistik Indonesia Tahun 2019. Jakarta: BPS-Statistics Indonesia.

Fairuza, M. (2017). Kolaborasi Antar Stakehokder Dalam Pembangunan Inklusif Pada Sektor Pariwisata (Studi Kasus Wisata Pulau Merah Di Kabupaten Banyuwangi). Jurnal Kebijakan dan Manajemen Publik, Vol.5 No.3.

Fanny Simanjutak, S. (2017). Peran Local Champion Dalam Pengembangan Community Based Tourism (CBT) Di Desa Wisata Candirejo Magelang. Jurnal Pengembangan Kota (JPK), Vol.5 No.2 (190-199). 
Handayani, S. M. (2016). Agrowisata Berbasis Usahatani Padi Sawah Tradisional Sebagai Edukasi Pertanian (Studi Kasus Desa Wisata Pentingsari). Jurnal Habitat, Vol.27 No.23 (133-138).

Heru Permana, F. S. (2016). Faktor - Faktor Yang Mempengaruhi Keputusan Petani Dalam Pemanfaatan Lahan Rawa Lebak Pada Usahatani Padi Sawah Di Desa Pasar Terusan Kapanewon Muara Bulian Kabupaten Batanghari. . Sosio Ekonomika Bisnis, Vol.19 No.1.

Muhammad Ali Zuhri Mahfud, B. S. (2015). Peran dan koordinasi stakeholder dalam pengembangan kawasan minapolitan di Kecamatan Nglegok, Kabupaten Blitar. Jurnal Administrasi Publik (JAP), Vol.3 No.2 (2070-2076).

Patminingtyas, T. U. (2020). Kolaborasi Stakeholder Dalam Pemberdayaan Masyarakat Berbasis Komunitas Di Kampung Wolulas (Studi Kasus di RW 18, Kelurahan Turen, Kabupaten Malang). Malang: Universitas Muhammadiyah Malang.

Peswita, I., \& Harini, R. (2013). Faktor dan Pengaruh Alih Fungsi Lahan Pertanian terhadap Kondisi Ekonomi Penduduk di kabupaten bantul (Kasus Daerah Perkotaan, Pinggiran, dan Pedesaan tahun 2001-2010). Jurnal Bumi Indonesia, 96-103.

Siti Nuraeni, T. I. (2018). Respon Petani terhadap Kebijakan Lahan Pertanian Pangan Berkelanjutan di Kelurahan Kersanagara, Kapanewon Cibeureum, Kota Tasikmalaya, Provinsi Jawa Barat. Jurnal Ilmiah Mahasiswa Agroinfo Galuh, Vol.4 No.3 (848-855).

Sugiyono. (2017). Metode Penelitian Kualitatif. Bandung: Alfa Beta.

Utama, I. (2015). Agrowisata Sebagai Pariwisata Alternatif. Retrieved Maret 30, 2020, from http://www.researchgate.net/publication/277074027_AGROWISATA_SEBAGAI_PA RIWISATA_ALTERNATIF

Wakka, A. K. (2014). Analisis Stakeholders Pengelolaan Kawasan Hutan dengan Tujuan Khusus (KHDTK) Mengkedek, Kabupaten Tana Toraja, Provinsi Sulawesi Selatan. Jurnal penelitian Kehutanan Wallacea, Vol.3 No.1, 47-55. 